\title{
Vagalampos, vagalampi:fantasmagorias na dramaturgia e na tradução pirandellianas no Brasil
}

\section{Vagalampos, vagalampi: Phantasmagoria in Pirandellian dramaturgy and translation in Brazil}

Maria de Lourdes Rabetti (Beti Rabetti) ${ }^{1}$

Ao professor Sábato Magaldi, in memoriam, a quem devo incentivo e justificativa para traduzir I giganti della montagna, de Luigi Pirandello

A Maria Helena Torres, por antiga e insubstituível parceria nas quase intermináveis rodadas em busca da melhor expressão para o que quero dizer 


\section{Resumo}

O presente texto deseja compreender formas de mapeamentos e de leituras da presença de Pirandello no Brasil, relacionadas a modos de ver, ou não ver, sua recepção, crítica e de cena. Formas que, seletivas e predominantes, acarretam delimitações inquietantes também para o exercício tradutório. O "cerebralismo" presente na produção artística do autor seria o principal fio histórico condutor de modos de ler o dramaturgo no Brasil, a ponto de nos levar a considerar o "mito" Os gigantes da montanha, em seu inacabamento e alta e fantasmagórica voltagem poética, "obra falha". Nessa esteira, traduções brasileiras desse texto tornaram-se invisíveis, ausentes, inexistentes.

Palavras-chave: Tradução teatral; invisibilidade; poesia pirandelliana; incabamento
The present text wishes to understand ways of mapping and reading the presence of Pirandello in Brazil, related to ways of seeing, or not seeing, his reception, critically and scenically. Forms that, selective and predominant, entail disturbing delimitations also for the translation exercise. The "cerebralism" present in the author's artistic production would be the main historical thread leading to ways of reading the playwright in Brazil, to the point of considering the "myth" The Mountain Giants, in its incompleteness and high and phantasmagoric poetic voltage, a "faulted work". In this sense, Brazilian translations of this text became invisible, absent, non-existent.

Keywords: theatrical translation - invisibility - Pirandellian poetry - incompleteness

E-ISSN: 2358.6958

\footnotetext{
1 Profa. colaboradora do Programa de Pós-Graduação em Artes Cênicas da Universidade Federal do Estado do Rio de Janeiro (Unirio); profa. visitante da Universidade Federal de São João del-Rei (UFSJ) (2018-2020). Pesquisadora do CNPq. mlrabetti@gmail.com

O texto resulta de projeto de pesquisa, financiado pelo CNPq, dedicado aos estudos sobre a "Tradução em cena: contribuição para uma história da tradução teatral no Brasil - confrontos e experimentações" (2011), nesse momento em sua segunda parte "Traduções, tradutores: invisibilidade e anonimato na história do teatro".
} 
Quando se tem em mente a vasta obra teórica, literária e dramatúrgica de Pirandello, também diretor teatral e filólogo, pode-se arriscar afirmar que o dramaturgo italiano é, em grande parte, desconhecido no Brasil. Sobretudo porque sua poesia nos chega amortecida pelo sobrepeso de determinada visão, do Pirandello "cerebral", a permear especialmente seu teatro, prevalentemente abordado pela questão da metateatralidade. Nessa medida, no texto e na cena, sua "trilogia metateatral" Seis personagens à procura de um autor [Sei personaggi in cerca d'autore (1921)], Cada um a seu modo [Ciascuno a suo modo (1924)] e Esta noite se representa de improviso [Questa sera si recita a soggetto (1929-1930)] - configurou-se no Brasil como uma espécie de "núcleo duro", respondendo por uma estreita porta de acesso, quase sem chancela, para travessias mais amplas, generosas, a permitir maior visibilidade à inteireza do autor.

A ênfase demasiada na metateatralidade tende a resumir, ou reduzir, a questão temática, de conteúdo, a uma análise de sua dramaturgia destinada principalmente a desvelar o pensamento do autor sobre o homem, sobre o teatro; ênfase que quase sempre tende a deixar escapar, seja à análise mais formal, seja a uma leitura mais sensível, o alcance de uma poética pessoal maior, presente em seus diferentes tipos de texto teatral, e dessa forma impedindo autor e leitor de mais pleno gozo de sua obra. ${ }^{2}$

Nessa estreita medida, insisto, dadas a grandeza e a complexidade da obra do autor italiano, sua dramaturgia, em boa parte dos casos tomada por certo caráter documental, revelador de seu pensamento, rende-se, opaca, à percepção de sua exuberância poética. Assim, e me referindo exclusivamente ao âmbito teatral, acredito poder considerar sua obra dramática poética por excelência, Os gigantes da montanha - presente no Brasil por intermédio de dois tradutores, em duas traduções realizadas no espaço de mais de 20 anos, para encenações de companhias teatrais de diferentes cidades brasileiras -, um caso positivo. Positivo e de grande relevância para o tema que se está discutindo, qual seja o da invisibilidade de certo Pirandello, estabelecida entre nós, nos estudos e na cena, por uma tradição de entendimento, de recepção do autor, que, com seus prismas relevantes mas excessivamente dominantes, acabou por sugerir uma angulação única para sua abordagem e que trouxe desdobramentos para o problema que estamos focalizando quanto à invisibilidade e à impossibilidade de sua tradução - problema a que tradução e cena em alguns momentos pareceram resistir.

Como bem disse, nos anos 60, um de seus estudiosos mais fecundos, senão pioneiro, no Brasil, em prefácio à primeira publicação de uma peça de Pirandello entre nós, traduzida por Ruggero Jacobbi, "o pirandellismo ameaça engolir Pirandello" (Magaldl, 1966, p. V).

\footnotetext{
2 A versão original do presente texto, traduzida para o português e atualizada para a presente publicação, foi elaborada em língua italiana e destinada à conferência proferida na Universidade de Pádua em 15 de abril de 2015, no âmbito da 2a Missão de Trabalho do Acordo de Cooperação Internacional Unipd-UNIRIO (2013-2018). Dessa forma, à sobreposição de duas versões realizadas pela própria autora/tradutora, parecem se sobrepor também dimensões de oralidade, que não se pretendeu eliminar.

Todos os esforços foram dispendidos para localizar os detentores de direitos autorais sobre imagens, e a autora coloca seu texto disponível para atualizações de referências e obtenção de autorizações diretas dos detentores nos dois casos em que isso não foi possível: fotos de Jayme Costa como "senhor Ponza" e de Cleyde láconis como "llse".
} 


\section{Documentos ou monumentos: em meio a listagens, mapeamentos e arquivos ${ }^{3}$}

Ditada por objetivos específicos, em 2015 foi realizada busca de obras teatrais do autor publicadas ou encenadas no Brasil, inicialmente por meio de listagens ou mapeamentos, muitas vezes tomados por exaustivos. Essa busca, agora parcialmente atualizada, parece continuar a reafirmar que a ênfase da leitura acima referida ainda prevalece entre nós.

Talvez se pudesse verificar, enfim, a hipótese de que mapeamentos mais completos ou quase retratos seletivos de obras e de encenações - e cujos esforços de seriedade são meritórios em muitos casos - despontem como contribuições para que se desvie o olhar do Pirandello poeta, de sua poesia transbordante em muitas obras dramáticas. E de que é preciso continuar em busca da plenitude do autor, que escapa à evidência em mapeamentos acerca de sua presença dramatúrgica entre nós.

Ainda que incompleta, a pesquisa quantitativa de peças teatrais traduzidas e de ensaios recentes - em listagens de referência, e em particular no mais restrito âmbito de estudos acadêmicos que delas se utilizam, ${ }^{4}$ mas também em obras sobre o autor publicadas por grandes casas editoriais, que garantem maior tiragem e circulação de obras, como, por exemplo, as da cidade de São Paulo, com predomínio da Perspectiva, ligada à Universidade de São Paulo ${ }^{5}$ - reitera a presença do problema acima apontado, revelando a forma fragmentária e "tendencial" da recepção da obra de Pirandello e ainda espelhada nos escritos sobre o autor. ${ }^{6}$

Por fim, tal busca, que coletou indicadores para uma análise qualitativa, permitiu revelar o fato de certo teor de invisibilidade de Pirandello entre nós, estendido sobre suas traduções, recobrir os próprios mapeamentos e listagens selecionados.

Mapeamentos são importantes, como se sabe, desde que não sugiram completude, e os esforços das listagens observadas são louváveis, mas em muitos casos poderiam ser menos assertivos. A título de exemplo, vale referir a dissertação de mestrado de Pasqualini (2009), disponibilizada na internet e que elenca no final "Traduções de Obras de Pirandello no Brasil (Pasqualini, 2009, p. 108-111), incluindo contos, novelas, peças teatrais e ensaios. A rigor, a dissertação reproduz substancialmente o trabalho de referência realizado por Fabris \& Fabris (1999), que, sob os títulos "Traduções de Obras de Pirandello no Brasil" e "Principais montagens de Pirandello no Brasil", faz parte do ensaio "Presença de Pirandello no Brasil", que conclui o li-

\footnotetext{
3 A preciosa discussão do historiador Jacques Le Goff (1990, p. 462) sobre esses "dois tipos de materiais [da memória]: os documentos e os monumentos, [sendo] os monumentos, herança do passado, e os documentos, escolha do historiador", foi bastante inspiradora para as questões discutidas neste segmento do texto.

4 Foi muito interessante e oportuna a busca na web, mediante entradas por palavras-chave determinadas por nosso objetivo de detecção de modos de leitura de Pirandello no Brasil, inicialmente de caráter exclusivamente quantitativo (mas sem pretensão de exaustividade), dado que permitiu verificar leituras e utilizações dos próprios mapeamentos por textos monográficos acadêmicos, resultantes de pesquisas de conclusão de pós-graduação.

5 Editora responsável, diga-se, por duas importantes publicações teatrais recentes sobre o autor: Guinsburg, J. (org.) (1999, com reimpressão em 2009) e Ribeiro (2010).

6 Destaca-se que, ainda com relação a 1999, o que predominava era o que se pode perceber como compreensão "fragmentária" de sua obra, contribuindo para o que se está considerando certa "invisibilidade" frente ao próprio autor, sem entrar ainda no problema da invisibilidade de sua tradução. Ressalta-se também a "existência de uma fortuna crítica que, exceto em alguns casos, quase nunca saiu do estrito âmbito do pirandellismo e, portanto, não se demonstrou capaz de trazer contribuições significativas para a análise de sua poética", como diziam as autoras de ensaio complementado justamente com a mais importante e mais utilizada listagem como referência a respeito da presença de Pirandello no Brasil (Fabris \& Fabris, 1999, p. 396). Lembre-se ainda que a mesma obra tem sua primeira reimpressão em 2009.
} 
vro Pirandello: do teatro no teatro (Guinsburg, 1999, p. 385-405). ${ }^{7}$ Também Kremer (2012) em ótimo trabalho de mestrado sobre duas traduções brasileiras de Vestir os nus [Vestire gli inudi], de Pirandello, refere ao final a lista de montagens dessa peça, lista produzida por Fabris \& Fabris, porém atualizada e creditando corretamente sua fonte. Para o tema de que se está tratando, é bastante oportuno observar ainda que, em 2011, Kremer publicara "exercício comentado" de tradução de um poema de Pirandello, compreendendo Pirandello poético como o autor de poesias, nas quais se teria iniciado aos 16 anos, e mencionando já no resumo do texto que

como não existe no Brasil nenhuma tradução de sua obra poética, a autora propõe sua própria tradução de um dos tantos poemas de autor muito conhecido pelo seu teatro e sua narrativa, mas tão desconhecido no âmbito da poesia [...] [para em seguida, no parágrafo introdutório voltar a observar que] Luigi Pirandello (1867-1936), escritor e dramaturgo italiano dos mais importantes do século passado, é conhecido principalmente pelo seu teatro inovador e por seus romances, muitos dos quais traduzidos para diversos idiomas. O público, porém, conhece pouco a obra poética de Pirandello. [...]. Pirandello não foi inovador na estética de sua poesia; seguiu os padrões líricos clássicos de forma e metro, embora não correspondesse a nenhuma corrente literária de seu tempo. $O$ mais importante dessa produção poética são suas ideias, seus temas, sua visão de mundo, que continuará posteriormente nos romances e no teatro. (Kremer, 2011, p. 1, grifos nossos)

Voltando à questão dos mapeamentos, diferenças quanto ao problema das listagens podem ser notadas na interessante dissertação de Sinésio da Silva Bina (2007), que, em seu estudo sobre a personagem dramatúrgica em Seis personagens... não inclui qualquer catálogo de obras de Pirandello traduzidas no Brasil, referindo, no entanto, em meio a excelente bibliografia, obras que resistiram à tentação das listagens.

Da documentação consultada para o presente trabalho, a rigor, em cobertura ainda bastante preliminar, alguns dados significativos se destacam. $O$ primeiro deles é o que indica sempre, além da incompletude e fragmentação dos mapas, a demanda para descobrir primados e origens, acerca do início da presença pirandelliana no Brasil. O segundo dado, bastante significativo no âmbito de estudos históricos historiográficos, em que se pretende inserir o presente texto, é o que aponta para mapeamentos, sintéticos ou ansiosos por amplas coberturas, sem inclusão, no entanto, de pesquisa em dois importantes acervos de peças teatrais traduzidas no Brasil: o da Sociedade Brasileira de Autores Teatrais (SBAT), com sede nacional na cidade do Rio de Janeiro - grande repositório de peças teatrais montadas no Brasil (https://www. sbat.com.br/quemsomos), sem acesso direto, mas com possibilidade de contato, via cadastro@sbat.com.br ${ }^{8}$-, e o do antigo "Banco de Peças", hoje Fonoteca, da Universidade Federal do Estado do Rio de Janeiro (Unirio). Originária do Conservatório Nacional de Teatro (1953), depois Escola de Teatro da Fefieg (1969), ${ }^{9}$ essa Fonoteca

\footnotetext{
7 Em nota de complemento ao título do ensaio, as autoras informam: "Este texto, publicado originalmente em italiano no v. 5 da revista norte-americana Pirandellian Studies (1995) foi atualizado para a presente edição" (Guinsburg, 1999, p. 385). A observação reaparece, por suposto, na reimpressão de 2009.

8 Na SBAT, como se verá, localizei nos anos 90 a tradução de Os gigantes da montanha, de autoria de Alberto D'Aversa, em versão datilografada, enviada a mim digitalizada, pelo funcionário Sérgio Santos, a quem expresso publicamente meu agradecimento, por esse e tantos outros trabalhos em que pude contar com seu auxílio.

9 Federação das Escolas Isoladas do Estado da Guanabara. "No ano seguinte [1979], com a criação da UNIRIO, concretizou-se a instituição dos cursos
} 
ainda consiste em importante repositório brasileiro de peças teatrais - aí incluídas as traduzidas para montagens teatrais, acadêmicas ou não, e muitas jamais publicadas, de circulação talvez mais restrita, mas de conhecimento antigo e bastante difundido na cidade, com acesso aberto - e que bem poderia se configurar como detentor de especiais coletâneas de "obras raras" traduzidas, disponíveis à consulta e à pesquisa, de que se tem pouco conhecimento em âmbito nacional. (http://www.biblioteca. Unirio.br/acervo/acervos-especiais). Veja-se o quadro abaixo, gentilmente enviado, durante a preparação da conferência de 2015, por Isabel Grau, então bibliotecária responsável pela Biblioteca Setorial do Centro de Letras e Artes da UNIRIO, e agora atualizado pelos funcionários Luis Miguel Ferreira e Bárbara Ribeiro, a surpreender, em certos casos, até mesmo listagens mais conhecidas:

\begin{tabular}{|l|l|l|}
\hline \multicolumn{1}{|c|}{$\begin{array}{c}\text { Número } \\
\text { de } \\
\text { chamadítulo }\end{array}$} & \multicolumn{1}{c|}{ Tradutor } \\
\hline 077 & Assim é se vos parece & \\
\hline 02500 & Assim é (Se lhe parece) & Brutus Pedreira \\
\hline 465 & Belavida & Millôr Fernandes \\
\hline 3005 & Cada um ao seu modo & Cláudio Corrêa e Castro \\
\hline 396 & O dever do médico & Pérola de Carvalho e J. Guinsburg \\
\hline 02195 & Encontrarse & s/inf. \\
\hline 02424 & Essa noite improvisamos & Millôr Fernandes \\
\hline 02508 & Os gigantes da montanha & Nydia Licia \\
\hline 1463 & Henrique IV & Beti Rabetti \\
\hline 790 & O homem da flor na boca & Adaptação: Paulo de Tarso \\
\hline 1520 & O imbecil & s/inf. \\
\hline 02618 & O jarro & R. Magalhães Jr. \\
\hline 2891 & Liolá & s/inf. \\
\hline 2903 & Não se sabe como & Mário da Silva \\
\hline 346 & A patente & Rugero Jacobbi \\
\hline 768 & Seis personagens à procura de um autor & Gilberto Augusto \\
\hline 1772 & Seis personagens à procura de um autor & Brutus Pedreira \\
\hline 2798 & O torno & Virgínia Mendes \\
\hline 2647 & Vestir os nus & Ruggero Jacobbi \\
\hline 3173 & Assim é se lhe parece & Sérgio N. Melo \\
\hline 3191 & O enxerto & Aurora F. Bernardini \\
\hline
\end{tabular}

Peças traduzidas de Luigi Pirandello disponíveis no acervo da Fonoteca da BSCLA/UNIRIO. Peças digitalizadas, muitas vezes a partir de originais manuscritos ou datilografados, para uso acadêmico de montagens teatrais curriculares de alunos diretores ou atores da Escola de Teatro. Quadro elaborado por Isabel Grau, Bárbara Ribeiro e Luis Miguel Ferreira, finalizado em maio de 2019 e aqui reproduzido. Aos funcionários, meu público agradecimento.

Não seria possível deixar de referir a presença de traduções de peças de Pirandello, em meio à importante coleção de peças teatrais - muitas datilografadas ou

superiores em Teatro. E a Escola de Teatro da UNIRIO consolidava-se como a única escola de nível superior a oferecer todos os cursos na área". Ver resumido, mas interessante histórico para a percepção da importância do repositório em pauta: Histórico - Escola de Teatro http://www.unirio.br/cla/escoladeteatro/historico. Acesso em: 25 jun. 2019. 
manuscritas, muitas com indicações claras de autoria e outras com indícios de vários tipos, incluídos aqueles sobre sua encenação -, no acervo da Biblioteca Jenny Klabin Segall, em São Paulo, parcialmente acessível em http://www.mls.gov.br/biblioteca/ catalogo-online/ e http://www.bjksdigital.museusegall.org.br/index.html.

Da mesma forma, não se pode deixar de referir os acervos (Cedoc e Biblioteca) da Fundação Nacional de Artes (Funarte) (http://www.funarte.gov.br/), com sede no Rio de Janeiro, em que podem ser encontradas raras edições de originais de Pirandello e algumas traduções.

Sem esquecer os arquivos do Serviço de Censura de Diversões Públicas (SCDP), local de depósito obrigatório e solicitação de autorização referente ao que se pretendia levar à cena nos anos de chumbo da ditadura brasileira e hoje abrigadas no Arquivo Nacional ("Peças Teatrais, do fundo do Serviço de Censura de Diversões Públicas (SCDP), custodiado pelo Arquivo Nacional") e acessáveis no Sistema de Informações do Arquivo Nacional (SIAN), pelo endereço http://sian.an.gov.br/sianex/consulta/login.asp.

E para estender a questão, apenas mais uma vez, sobre importantes depositários de peças teatrais, não há que deixar de referir também o fundamental acervo de peças teatrais da Biblioteca Nacional. ${ }^{10}$

De todo modo, tendo em vista os objetivos mais específicos do presente texto, é preciso dizer que as listagens encontradas nas buscas referidas - publicadas e/ou reproduzidas, quando não apenas citadas em textos de conclusão de pós-graduação disponibilizados na web -, para a eficácia de seu compartilhamento e levando em conta que se abrem, como se viu, para a possibilidade de se constituir como "obras de referência", necessitariam, tanto na perspectiva historiográfica de pesquisa, como contribuição ao acesso de novos pesquisadores, indicar os arquivos, ou fundos, em que foram coletados os dados e as fontes nelas encontradas, evitando, assim, equívocos de leituras que sugiram completude.

Alguns destaques merecem ser referidos, mesmo que em âmbito de inicial abordagem quantitativa, como a que fizemos até o momento. Quanto a traduções de Pirandello no Brasil - a consultar a listagem que se está considerando como de referência (Fabris \& Fabris, 1999; 2009) - no âmbito do teatro, ressaltam as peças da trilogia metateatral, despontando marcadamente entre elas Seis personagens à procura de um autor, com pelo menos três traduções de 1972 a 1999 e sete montagens, entre 1927 e 1983 (seis em dez anos, entre 1951 e 1960), em longa carreira que se teria iniciado com a estreia da peça no Brasil, no original e em 1927, justamente pela Compagnia del Teatro d'Arte di Roma. ${ }^{11}$

10 Além de referir a entrada https://www.bn.gov.br/tags/teatro (acesso em: 17 jun. 19), vale lembrar o importante trabalho de mapeamento desse acervo, realizado por Maciel (2015), como pesquisador residente da BN, e presente neste dossiê: https://www.bn.gov.br/producao/documentos/biblioteca-dramatica-brasileira-acervo-fundacao-biblioteca. Acesso em: 17 jun. 2019.

11 De acordo com a listagem matriz e as demais referidas, mas também segundo Dugo (2017, p. 82), por exemplo, quando afirma que "il primo allestimento scenico di Sei personaggi in cerca d'autore venne realizzato in italiano nel 1927 durante la tournée della Compagnia Teatro d'Arte di Roma diretta da Pirandello". Não foi o caso, dentro da delimitação do objetivo central deste texto, de perscrutar, como se deve, trajetos de montagens pirandellianas, no original ou em traduções brasileiras. É obrigatório, entretanto, referir que, até onde pude verificar, com vistas a desenvolver outras pesquisas, a primeira montagem de Sei personaggi... em língua italiana no Brasil teria ocorrido, no Rio de Janeiro, em julho de 1923, pela Companhia Dramática Italiana do Teatro Argentina (Roma), sob a direção de Niccodemi (Dario Niccodemi, que desempenhou papel fundamental para a introdução de Pirandello no Brasil, reconhecido por Oswald e Menotti del Picchia), e com Vera Vergani encabeçando o elenco. E, não resistindo à tentação das estreias e das origens, merece ser lembrado que essa não é a estreia do autor no Brasil, que teria ocorrido em junho de 1923, no Theatro Municipal do Rio de Janeiro, com Maria Melato em Vestire gli ignudi, em companhia que, em 9 de julho, 
Sempre para o caso de Seis personagens..., destacam-se nas listagens consultadas, dentre os primeiros tradutores, Menotti Del Picchia, 1951, para o TBC, dado que consta também da Enciclopédia Itaú Cultural (http://enciclopedia.itaucultural.org.br/ evento398291/seis-personagens-a-procura-de-um-autor, acesso em: 2 jun. 2019), tradução não publicada; e Brutus Pedreira, para espetáculo de 1959, com tradução premiada, segundo a mesma Enciclopédia (http://enciclopedia.itaucultural.org.br/ evento397582/seis-personagens-a-procura-de-um-autor, acesso em: 2 jun. 2019) e publicada em 1976, pela editora Abril, de São Paulo. ${ }^{12}$

Duas traduções mais recentes, não constantes das listagens referidas, e publicadas no espaço de apenas 12 anos, merecem nota: a primeira, de 1999, sempre no âmbito do livro Do teatro no teatro, organizado por Guinsburg (1999, p. 181-239), aparece sob o título Seis personagens à procura de um autor, assinada por Jacob Guinsburg e Roberta Barni; a segunda, de 2004, de título Seis personagens à procura de autor: uma comédia a ser criada, é de Sérgio Flaksman, publicada por Peixoto Neto em São Paulo.

Além dessas edições brasileiras da emblemática Seis personagens... é preciso referir, ao menos, alguns destaques no âmbito de traduções teatrais mais recentes do autor, entre as quais a importante publicação, pela Carambaia, de São Paulo, em 2017, de cinco peças, em atos únicos, traduzidas por Maurício Santana Dias: $O$ torniquete, Limões da Sicília, A patente, O homem com a flor na boca, O outro filho, lembrando também a de Assim é (se lhe parece), realizada por Sergio Nunes Melo e publicada em 2011 pela Tordesilhas, também de São Paulo.

Sem deixar de incorrer no problema da busca de origens, ao consultar as mesmas listagens e com base em algumas considerações de estudiosos, pode-se dizer, com boa margem de acerto, que, quanto a traduções publicadas, Pirandello estreou no Brasil pela Editora Brasiliense (Brasiliense de bolso, série Teatro Universal, 16), de São Paulo, em 1966, com Vestir os nus, assinada por Ruggero Jacobbi e com prefácio de Sábato Magaldi; vale lembrar que a tradução fora realizada bem antes, destinada à montagem de espetáculo de mesmo título dirigido por Alberto D'Aversa, para o Teatro Brasileiro de Comédia (TBC) em 1958.

Quanto à presença de Pirandello traduzido, no entanto, é dever historiográfico proceder novamente a alguns ajustes - mesmo que de modo breve (ver Rabetti, 2017a; 2017b) -, dado que o autor já estreara em língua portuguesa no Brasil em 1924, por uma companhia popular de teatro, a Companhia Brasileira de Comédias de Jayme Costa. E a peça de estreia, por uma companhia popular itinerante, foi Cosi è (se vi pare), traduzida por Pois... é isso!, tendo Jayme Costa no papel do senhor Ponza, em primeira intepretação de Pirandello em língua portuguesa nos palcos brasileiros.

leva à cena em São Paulo também Cosi è, se vi pare, no Teatro Sant'Anna (ver Rabetti, 2017a, p.7; 2018, p. 12 e seguintes).

12 Na Biblioteca Segall, de São Paulo, foi encontrado exemplar datilografado da peça, que indica no cabeçalho, em texto manuscrito, "Seis Personagens. Trad. Menotti Del Picchia". Cotejado com versões que indicam autoria de Brutus Pedreira, não apresentou qualquer alteração. A mesma observação já fora feita por Sebastiana Fadda - pesquisadora da Universidade de Lisboa que participa do presente dossiê sobre a tradução teatral - por ocasião de seu pós-doutorado na UNRIO. De todo modo, como se viu, foi consultada, para esse caso especialmente, também a Enciclopédia Itaú Cultural e Dugo (2017). A versão digital da tradução de Brutus está disponível em https://ieacen.files.wordpress.com/2015/08/seis-personagens-c3a0-procura-de-um-autor.pdf. Acesso em: 20 maio 2019). 


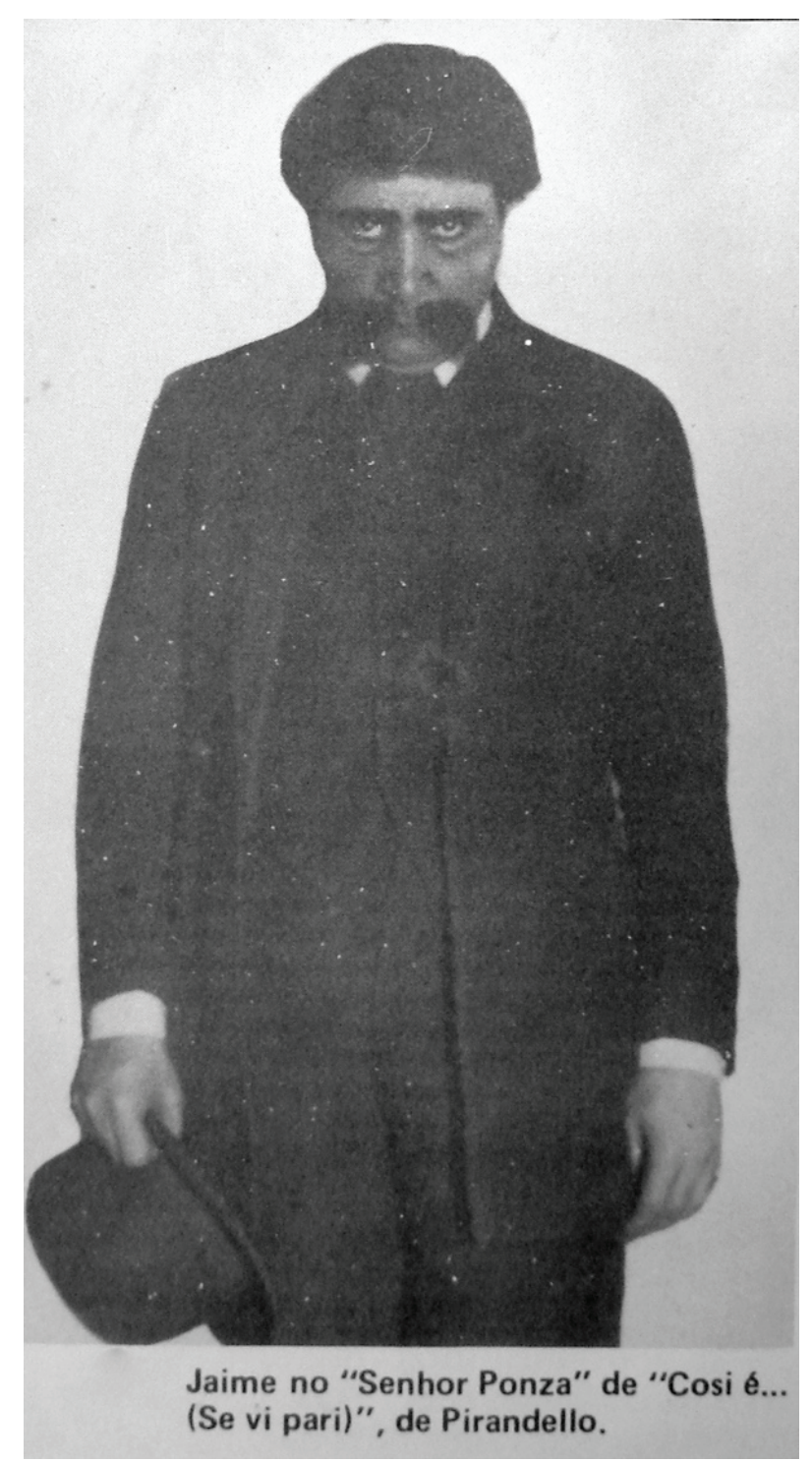

Cedoc, Funarte: Arquivo Jayme Costa [Anuário Casa dos Artistas, 1978]

Para finalizar este segmento, antes de passar ao tema mais pontual a ser enfocado - o caso de duas traduções de Os gigantes da montanha -, caberia comentar que a questão da "invisibilidade" de um certo Pirandello, que parece estender-se ao exercício de sua tradução, de modo geral vai além das listagens referidas, que, em muitos casos, representam louvável esforço não apenas de ordem literária e teatral, introduzindo-se certamente em pesquisas ou ensaios que, no entanto, muitas vezes incorporam, de forma categórica, dados que, na origem, não almejaram, como não deveriam, o definitivo. E que, para o âmbito dos estudos históricos, como se procurou demonstrar, mereceriam incorporar indicações referentes a fontes e acervos.

A título de conclusão provisória, e quanto ao problema da história da tradução no Brasil, observo que a tradução teatral, fundamental para a configuração de nosso teatro durante o século XIX e elemento crucial em momentos teatrais relevantes do século XX - porque não apenas meio de circulação e conversação singular entre culturas, mas componente fundamental do complexo fenômeno da cena teatral -, ainda raramente se coloca em questão; ou não é percebida como presença em meio ao circuito de suas montagens e sob diferentes ângulos pelos quais se queira observar o problema. 


\section{Os gigantes da montanha no Brasil: efemeridades protagonistas enredadas na trama definitiva del grande autore}

A respeito dessa obra pirandelliana, eu dizia já em 1991, reiterava em 2005, e gostaria de aqui relembrar, ainda uma vez, como tradutora:

Este "mito", a meio caminho entre "a fábula e a realidade", e cuja realização acompanhou Pirandello por muitos lugares e durante muitos anos, transcorre sempre, em última instância, no espaço de uma "ilha selvagem". E, devendo compor a trilogia de "mitos", ao lado de La nuova colonia e Lazzaro, resulta, literariamente, numa obra que poderia ser considerada inacabada. (Rabetti, 1991; 2005)

Os gigantes da montanha me parece caso importante a contribuir para a discussão que venho procurando estabelecer em torno do que percebo como problemas da invisibilidade da tradução teatral no Brasil, que, dadas suas variadas dimensões, pode ser tomada sob diferentes aspectos. Nesse sentido, parece necessário traçar, inicialmente, breve e provisória história da tradução dessa "obra falha" da dramaturgia pirandelliana no Brasil. Não sem antes, porém, lembrar que o texto original, I giganti della montagna, inacabado e pelo autor definido "mito", foi obra cuja elaboração acompanhou Luigi Pirandello por toda a vida: trata-se de longo e definitivo work in progress, que persistiu em sua incompletude.

Pleno de poéticas rubricas e de longas falas banhadas de alto teor lírico, como as do mago Cotrone, tem escrita esparramada, desrespeitadora de convenções quanto a gênero, unidades e extensões: um mito. Tais características e sobretudo seu involuntário, ou talvez inevitável, inacabamento a colocam nos limites de certa dramaturgia moderna, ali onde, ao mesmo tempo e de modo aparentemente ambíguo, teria amenizado suas dimensões reflexivas, filosóficas, pois nela se realiza, de modo emblemático, aquilo que Szondi (2001, p. 145) nos apresenta como aporte diferenciado de Pirandello para o drama moderno; nela se realiza, em plenitude poética, "o jogo da impossibilidade do drama".

Esse é um ponto de partida fundamental para a verificação um pouco mais atenta das críticas recebidas com sua entrada em cena entre nós, em relação à tradição do pirandellianismo a que já nos referimos.

As duas traduções brasileiras desse verdadeiro mito dramatúrgico, quase intangível, de que, até o momento, se tem alguma notícia - uma delas não foi publicada, a outra, publicada, alcançou duas edições - foram elaboradas com vistas a sua imediata encenação, uma em 1969, em São Paulo, a outra em duas diferentes montagens: a de 1991, no Rio de Janeiro. Posteriormente a sua publicação, já em segunda edição, estreou em 2013, em Belo Horizonte, e ainda percorre várias praças do país. 


\section{A tradução de Os gigantes da montanha de 1969, para a Companhia Teatro de Dois Mundos, São Paulo}

Da primeira tradução, de 1969, tive notícia mais precisa em 1990, quando iniciava as pesquisas para trabalho de dramaturgismo que desenvolvia na Companhia de Encenação Teatral, do Rio de Janeiro, sob a direção de Moacyr Góes, a quem eu sugerira o enfrentamento da poesia presente na obra dramática de Pirandello. A descoberta do texto traduzido deu-se justamente por meio de buscas junto ao acervo da SBAT, no Rio de Janeiro, no qual localizei uma versão datilografada que, na capa, indicava autoria de Alberto D'Aversa. Nela encontrei alguns problemas, especialmente ligados, por um lado, à utilização de expressões demasiadamente localizadas, datadas, que eu não encontrava no original italiano, e, por outro, a quebra de expressões idiomáticas utilizadas pelo autor. Suspeitei de sua autoria, nos anos 60, por parte de um tradutor de origem italiana e sobre isso conversei com o professor Sábato Magaldi, que encorajou fortemente uma nova tradução dado que considerava possíveis dificuldades que deveriam ter ocorrido no contexto da elaboração de D'Aversa, tendo em conta de modo especial, mas não exclusivo, o projeto e a implementação do ambicioso Teatro de Dois Mundos. Não só como tradutora, mas sobretudo como dramaturgista da Companhia de Encenação Teatral para a qual eu propusera a montagem de Os gigantes..., era questão a ser enfrentada e iniciaria então o processo tradutório, de que tratarei adiante.

Alberto D'Aversa, importante diretor teatral italiano a participar do processo de modernização do teatro brasileiro, atuando no Teatro Brasileiro de Comédia (TBC) e em diversas outras importantes companhias teatrais, foi também professor da Escola de Arte Dramática de São Paulo e crítico do Diário de São Paulo. Não se tem notícia, até o momento, de outras traduções que ele tivesse feito. ${ }^{13} \mathrm{~A}$ de Os gigantes da montanha ligou-se à montagem dirigida por Federico Pietrabruna em produção do Teatro de Dois Mundos - um projeto amplo para intercâmbio artístico-cultural entre Brasil e Itália, cuja primeira produção consistente teria sido essa montagem. A peça teria estreado em junho de 1969, no Theatro São Pedro, seguindo para o Rio de Janeiro, onde, a partir de julho, iria se apresentar no Teatro João Caetano, com cenografia e figurinos de Tulio Costa, cenógrafo que, como D'Aversa e outros homens de teatro italianos, integraram a equipe do (TBC) ao longo de anos seguidos. Destaque merecem ainda a atuação de Ziembinski, como Cotrone, e a de Cleyde Yáconis, como Ilse.

13 Seu importante trabalho como crítico teatral no Brasil foi objeto de pesquisa, resultante em 1979 em dissertação de mestrado (ver Mercado Neto, 1979). 




Cleyde Yáconis e Ziembinski em Os gigantes da montanha, 1969 (Astros em Revista, 2012) ${ }^{14}$

A boa notícia acerca dessa primeira tradução de I giganti della montagna no Brasil, infelizmente "último trabalho para o teatro" de Alberto d'Aversa, é que - embora não tenha sido publicada e, como tantas outras de que se falou, não tenha sido merecedora de visibilidade por ocasião de sua encenação, resumindo-se sua presença na imprensa quase que exclusivamente a dados de ficha técnica de algumas matérias de lançamento ${ }^{15}$ - hoje são encontradas referências sobre sua existência em repositórios de peças teatrais como o da SBAT. Singular e triste referência a essa tradução foi feita em matéria de Yan Michalski no Jornal do Brasil por ocasião da morte de D'Aversa: iniciando com a formação na Itália e a carreira de D'Aversa no Brasil, Michalski (1969, p. 2) afirma que: "seu último trabalho para o teatro foi a tradução de Os gigantes da montanha, de Pirandello, que estreou em São Paulo poucos dias depois de sua morte".

14 Consultado o blogger de Astros em Revista, Elias Orias me respondeu não ter qualquer objeção quanto ao uso das fotos, que, de todo modo, não eram de sua propriedade, tendo sido digitalizadas de antigos programas de peças e revistas. Disse ainda não ter informação sobre o fotógrafo. (Orias, correspondência eletrônica, jun. 2019)

15 Consultado o Jornal do Brasil, via Hemeroteca Digital da BN, para 1969 - ano de suas estreias em São Paulo e no Rio de Janeiro, com a chamada "gigantes da montanha", foram encontradas 11 ocorrências. Delas, apenas duas referem a tradução de Alberto D’Aversa; uma aparece na mencionada crônica de Yan Michalski. Segundo a Enciclopédia Itaú Cultural), a tradução teria sido premiada. (disponível em: http://enciclopedia.itaucultural.org.br/evento402857/os-gigantes-da-montanha. Acesso em: 14 jun. 2019. 


\section{A tradução de Os gigantes da montanha de 1990: exercício tradutório e dramaturgismo}

Como dramaturgista da Companhia de Encenação Teatral, desde agosto de 1990 conversava com Moacyr Góes, diretor da companhia, a "respeito das possibilidades de exercício que as difíceis e belas palavras da poesia pirandelliana" nos permitiriam "e sobre o sentido e a importância de trabalhá-las n[aquele] momento do nosso trajeto" (Rabetti, 1991; 2005, p. 11). ${ }^{16}$

Esse dado inicial aponta para existência de um processo tradutório voltado para uma montagem, mas especialmente relacionado ao exercício de dramaturgismo; realizado, aliás, de modo contínuo e por mais de seis anos no seio de um grupo teatral. Deve-se dizer, então, que os exercícios combinados de tradução e dramaturgismo, desenvolvidos no período de 1985 a 1991, resultaram numa versão brasileira da peça Os gigantes da montanha que apresenta, a meu ver, três características.

A primeira delas é investir com ênfase nas estratégias de preservação/versão possível da poesia pirandelliana, que percebi explodir de maneira retumbante em seu último e inacabado texto teatral, espraiando-se pela quase totalidade da peça.

A segunda é investir fortemente nas dimensões de oralidade da poesia proferi$\mathrm{da}$, que entendo intensamente almejada pelo autor desse "mito" - oralidade e poesia voltadas para pensar, pela experiência sensível, a possibilidade de diálogo e de encontro entre cena espetacular e público. A esse respeito, e mesmo tratando de tradução e dramaturgismo de outra peça (Marlowe, 1989), assim compreendi as implicações da duplicidade das funções de dramaturgismo e tradução e os desdobramentos visíveis nas dimensões de oralidade contempladas no ato tradutório, que bem valeriam também para o processo de construção de Os gigantes da montanha:

Aglutinando exercício de tradução e de dramatugismo, traduzir foi lento e caprichoso movimento paulatino, simultâneo ao processo de construção do texto cênico. Seus traços indicavam idas e vindas provocadas pelos experimentos da cena em que a palavra escrita era, concomitantemente, voz dos atores, em modulagens advindas da imbricação entre texto impresso e texto da cena, expressivo de todas as dificuldades atoriais em formação e do próprio exercício do dramaturgismo e da encenação frente a texto de tal porte. [...] O que acabou por permitir, no entanto, o florescimento de dois dados cênicos interessantes e insuspeitados, para o problema em questão: inicialmente, por não ter impedido, ao fim, que a última camada de tratamento cênico do forte e impositivo texto matricial fosse matizada pela mobilidade e fluidez da palavra proferida, pelas oralidades diversas que iam interferindo na tradução do texto e construindo a polifonia da cena; e depois, como se disse, por integrar a força da tradução do texto e da ação dramaturgista ao conjunto dos elementos mais expressivos do espetáculo teatral encenado. (Rabetti, 2011, p. 454-455)

A respeito do vaivém que se instaura no processo tradutório entre "texto matri-

\footnotetext{
16 O texto-fonte trabalhado - I giganti della montagna - Mito - foi o publicado na coleção Opere di Luigi Pirandello, Maschere Nude II, da Editora Mondadori, de Milão: 1981, p.1305-1376, depositado na Biblioteca da Funarte. Meu público agradecimento a Joelma Neris Ismael e a Maria da Gloria F. Brauninger, pelo auxílio constante ao longo dos anos e, agora, pelo apoio em meu reencontro com a fonte original utilizada para a tradução dos Giganti. A tradução integral da peça foi autorizada pela Siae Prot. N. 2/1520/GN, Roma, 29/01/1991; registrada na Sbat (RJ), sob o no 28.305 - 18/06/1991 e no "Registro de Obras" (Biblioteca Nacional - RJ), sob o no de ref. 70622; I. 83; Fls. 497 - 17/06/1991]. Sua primeira publicação ocorreu em 2005, a segunda em 2013, sempre pela 7Letras, do Rio de Janeiro. Questões gerais sobre a tradução podem ser vistas em Rabetti $(1991,2005,2013)$.
} 
cial" e montagem cênica, bem a propósito de Os gigantes da montanha, eu dizia de Leon Góes que sua "voz e presença cênica colaboraram para que eu pudesse discernir e ter certeza de que, efetivamente, 'nós fazemos os fantasmas' e não apenas os 'criamos'" (Rabetti, 1991; 2005, p. 10).

A terceira característica - aos olhos da tradutora a de maior singularidade para a tradução e para a segunda de suas encenações entre nós, a da Companhia de Encenação Teatral, 22 anos após a primeira - é a que põe ênfase na dimensão protagonista do personagem Cotrone, pela tradutora dramaturgista compreendida como detentor por excelência da poesia pirandelliana de Os gigantes..., um alter ego do autor, que em longas falas, tomado por êxtase e inspiração, delira poeticamente, ultrapassando bastante os limites das falas mais "regulares"; das falas tradicionais e cotidianas da maioria dos demais personagens. É que, em Cotrone, a poesia pirandelliana rompe a cena e alcança a épica, faz-se narração, dando ao autor feito personagem teatral o estatuto de um arauto, aedo e bardo no seio de uma cena de teatro moderno. Essa, a meu ver, a mais bela dimensão da compreensão de Cotrone como narrador. Acredito poder dizer que no texto traduzido e na cena da Companhia de Encenação Teatral, o mago Cotrone, criador de fantasmas, faz-se "arquifantasma" na longa tradição dos fantasmas teatrais, proferidor epifânico das palavras que instauram a matéria de que é feita a cena possível, em tais bordas do "teatro moderno".

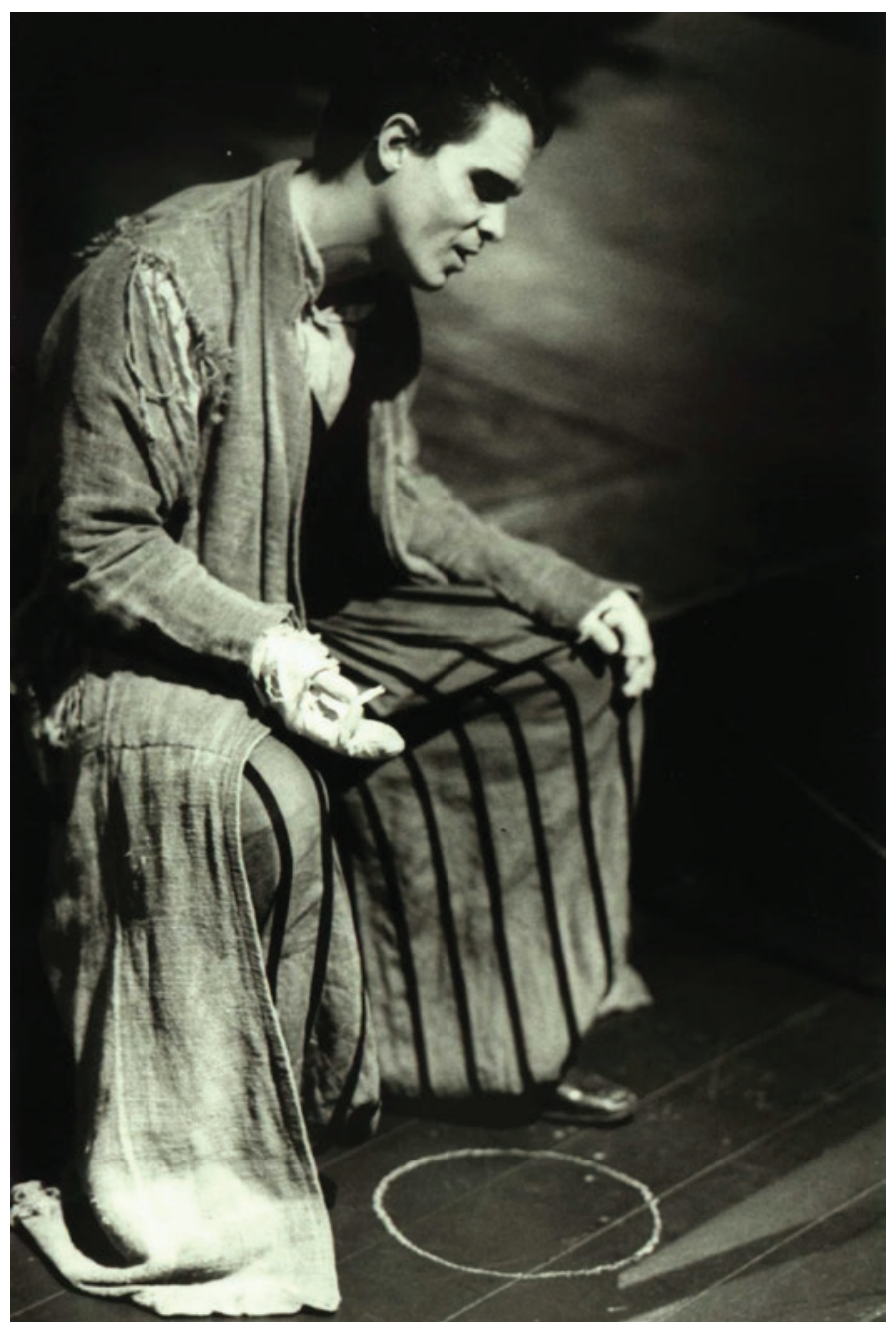

"Olhamos para a Terra, que tristeza!"

Leon Góes como "Ator"/Cotrone em Os gigantes da montanha, Rio de Janeiro, Companhia de Encenação Teatral, julho 1991.

Foto: Moacyr Góes. Acervo do ator 
A dar ainda mais singularidade a traços da tradução, está o fato de que aquele grupo teatral, ao longo de seus quase seis anos de trabalhos ininterruptos, construiu um personagem cênico, que passou a compor sucessivamente cada encenação, em qualquer peça que se levasse à cena, quase sempre com seu antigo casaco surrado: era o personagem do "Ator", que ora se acrescentava ao texto dramático encenado, ora assumia um de seus personagens. Para o caso de Os gigantes da montanha, tal papel "do Ator" criado por Leon Góes ao longo dos anos, justapôs-se ao personagem Cotrone, o velho mago criador de fantasmas, e seu autor. Tal carga de sobreposições rendeu-lhe ainda mais centralidade protagonista e, posto que condutor/narrador da cena, consequentemente fez explodir a poesia na tradução e no palco. Tal fato contribuiu fortemente para redobrar, na tradução, a ênfase lírica do narrador-personagem, aqui feito protagonista absoluto da encenação de Pirandello.

Os gigantes da montanha permaneceu em cartaz durante alguns meses, na pequena Sala 3, nos fundos do Teatro Villa-Lobos. A fortuna crítica quantitativamente bastante razoável, com cobertura jornalística dos principais periódicos do Rio e de São Paulo, iniciou-se no ano anterior - no rastro do sucesso de $A$ escola de bufões, quando Os gigantes era ainda apenas um projeto - abrindo-se, aliás, para matérias ou entrevistas com membros do grupo. Sua tradução, no entanto, permaneceu invisível. Nenhum comentário foi feito a respeito de sua existência: ou porque não fosse digna de nota, ou porque, enquanto pura e mera tradução, não se constituía como questão a ser percebida ou analisada como componente em jogo na montagem teatral. Permaneceu antes e durante a temporada, absolutamente inexistente aos olhos de público e crítica.

Em termos de certos aspectos relacionados ao que venho percebendo e discutindo sobre "invisibilidade" do tradutor e de sua tradução, na história da tradução teatral no Brasil, vale confirmar neste caso certos dados quantitativos. Em busca rápida na Hemeroteca Digital da Biblioteca Nacional, no Jornal do Brasil, um dos mais importantes veículos para a crítica teatral jornalística do período, foi possível registrar que referentes a 1990 e 1991 foram encontradas 119 ocorrências para "gigantes da montanha"; nelas, nenhuma referência à tradução de uma peça praticamente inédita entre nós. ${ }^{17}$

Entendo que à opacidade do olhar sobre a tradução de Os gigantes... - que se pretendeu calcada na busca da poesia pirandelliana, de sua lírica perscrutada e colhida na coloquialidade da prosa - fazia companhia, mais uma vez, a invisibilidade ainda presente nos anos 90; o Luigi Pirandello ofuscado ou "engolido" pelo "pirandellismo" da tradição crítica e dos palcos brasileiros ainda era o aqui presente.

\footnotetext{
17 Não pude desenvolver busca apurada ou "exaustiva" da fortuna crítica em torno da montagem, voltada para a tradução, ou não, mas, acredito que a amostragem obtida seja significativa. Por sua vez, vale destacar, pela diferença no rol, que, em comentário crítico ao espetáculo de Os gigantes... pelo Galpão em São Paulo, em setembro de 2013, 44 anos depois da primeira encenação brasileira da peça em língua portuguesa (segundo tradução de Alberto D'Aversa), ocorre a excepcionalidade do encontro de referências à tradução da peça novamente em cena, lembrando, aliás, que se trata de tradução anteriormente levada ao palco, 22 anos antes: "evitando uma excessiva duração e também cenas de complexa tradução cênica, o diretor optou por usar o recurso de narrar alguns trechos da peça. Foi utilizada a ótima tradução de Beti Rabetti, a mesma usada em 1991 na encenação carioca de Moacyr Góes. Tive o privilégio de ver Cleyde Yáconis e Ziembinsky em 1969...". Privilegiada fonte de informação e comentário que coloca em cena três montagens, bastante intercaladas, sem referir, no entanto, o tradutor da primeira (Cetra, 2013, disponível em http://palcopaulistano.blogspot.com/2013/09/os-gigantes-da-montanha.html, acesso em 20.05.2019). Como veremos adiante, ainda outra referência, rara e específica, a uma tradução brasileira é feita por Schenker (2013).
} 


\section{A tradução de Os gigantes da montanha - do livro às ruas: publicação pela 7Letras em 2005 e encenação pelo Galpão em 2013}

Fato é que, 14 anos depois de sua elaboração (1990-1991) e de sua primeira encenação (2005), uma tradução brasileira de I giganti della montagna (1931-1936), foi finalmente publicada entre nós. ${ }^{18}$

A título de prefácio, reproduzi o texto publicado no programa da peça (Rabetti, 1991) na época da encenação, destinado a tratar da tradução, a que acrescentei apenas uma breve nota informando que "a distância no tempo e da montagem teatral com a qual a tradução se envolveu facilitou a introdução de instâncias mais coloquiais, que me pareceram necessárias em algumas passagens" (Rabetti, 2005, p. 11). É possível perceber hoje que a passagem do tempo também fez ver que certa dimensão "mítica", em concepção diversa da agora tratada no presente texto, ainda atravessava o exercício tradutório, gerando certa distância reverenciadora da bela língua-mãe e de sua poesia.

Em 30 de maio de 2013, simultaneamente ao lançamento da segunda edição da tradução, que sofreu pequenas alterações em relação à primeira, estreia uma sua nova montagem, agora para ruas e praças - a praça do Papa em Belo Horizonte, Minas Gerais foi o local de estreia -, sob a batuta do Grupo Galpão e do diretor Gabriel Villela, renovando entre eles uma parceria que já ocorrera em duas das mais importantes e reconhecidas montagens do grupo: Romeu e Julieta, de Shakespeare, em 1992, na belíssima tradução em versos de Onestaldo de Pennafort, publicada em 1940 pelo Ministério da Educação e Saúde, e A rua da amargura, a partir do texto de Eduardo Garrido O mártir do calvário, em 1994.

A montagem de Os gigantes da montanha de 2013, também comemora os 30 anos de existência do Grupo Galpão. Trata-se, enfim, de uma montagem emblemática, significativa na história da cena contemporânea brasileira.

Daniel Schenker, crítico e ensaísta, em "Pirandello com a marca do Galpão" resume com muita propriedade o sentido de oportunidade que uma peça como Os gigantes da montanha apresenta para integrar-se à trajetória do grupo, ao mesmo tempo em que, sob direção de Vilella, imprime "sua marca" ao autor: por ocasião da apresentação da peça no Aterro do Flamengo no Rio de Janeiro, Schenker (2013, s.p.) comenta:

É possível identificar o Galpão na escolha de uma dramaturgia como a de $O s$ gigantes da montanha, de Luigi Pirandello - em tradução de Beti Rabetti, que já havia participado como dramaturgista desse texto em montagem de Moacyr Góes, no início da década de 90 -, distante do realismo (ainda que o grupo tenha transitado, recentemente, pela dramaturgia de Anton Tchekhov), e em toda a criação estética, que remete não só a outros trabalhos da companhia como à conhecida assinatura de Gabriel Villela: o detalhamento barroco presente nos figurinos (de Villela, Shicó do Mamulengo e José Rosa), a homenagem ao teatro evidenciada na cenografia (de Villela, Helvécio Izabel e Amanda Gomes), a evo-

18 A preparação do texto para publicação foi feita a convite de Ângela Leite Lopes, diretora da Coleção dramaturgias da Editora 7Letras do Rio de Janeiro, e de seu editor, Jorge Viveiros de Castro, ocupando o 110 lugar na excelente lista das traduções ali contempladas. 
cação artesanal de um clima fantasmagórico na iluminação (de Chico Pelúcio e Wladimir Medeiros), o expressivo emprego da música a serviço da cena (arranjos, composição e preparação musical a cargo de Ernani Maletta).

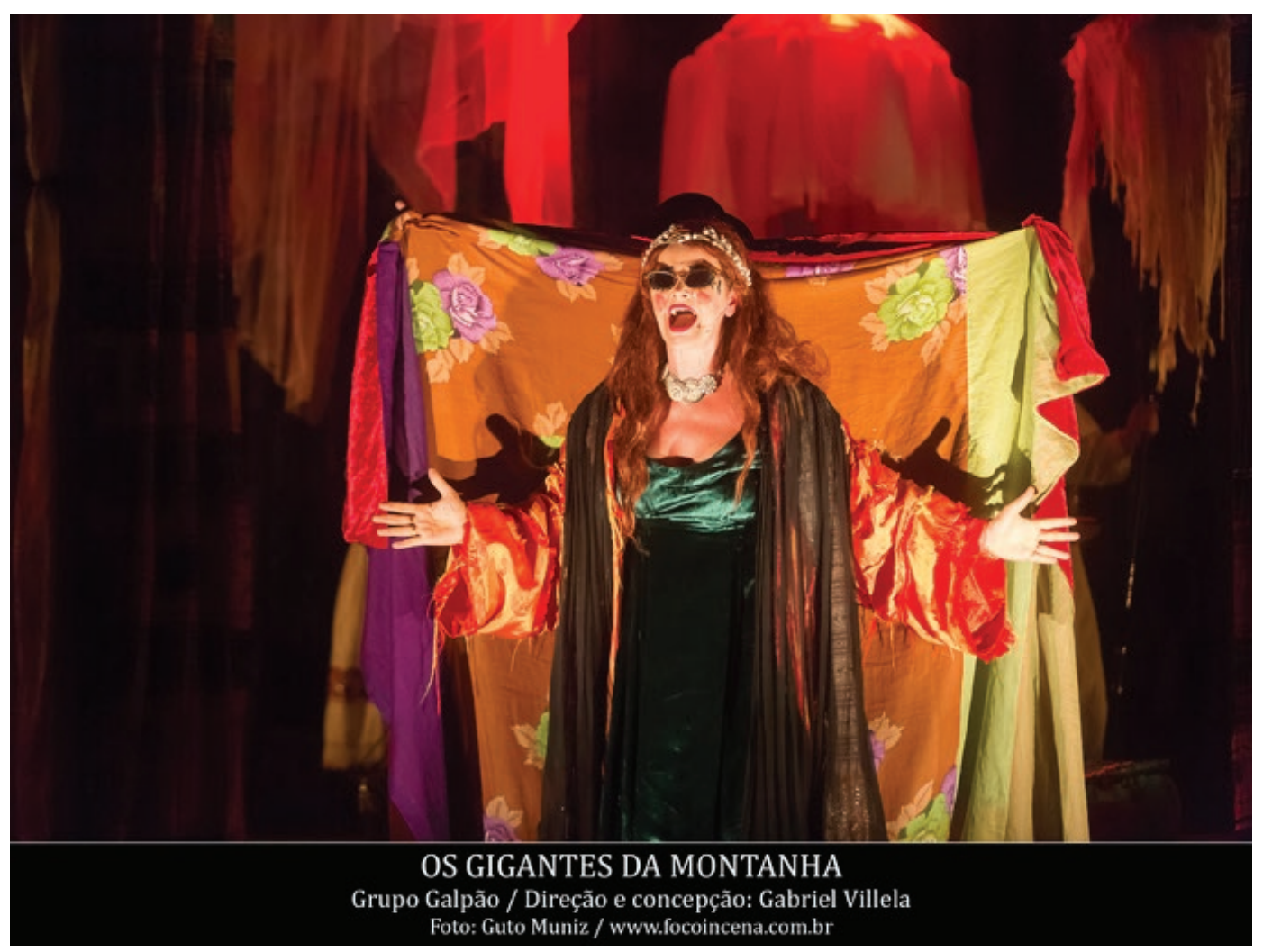

Ilse Paulsen (Inês Peixoto), protagonista dessa montagem de Os gigantes da montanha, canta "Vissi d'arte", ária para soprano da ópera Tosca, de Puccini, em imitação hiperbólica de Janis Joplin; modos de aproximação entre Pirandello e o público atual, fazendo circular erudito e popular (Araújo, maio de 2013). Ver também https://www.youtube.com/watch?v=V7s-5c0fdvc (049/1:38). Acesso em: 02 jun. 2019.

Observe-se, neste momento, em função do que discute na sequência, a decisão da tradutora frente à acepção mítica que a tradução procurou preservar da "obra-fonte", sem ajustes para enxugamentos, mas, ao contrário, incluindo extensas notas colhidas e traduzidas diretamente de obra anterior de Pirandello, La favola del figlio cambiato, de 1932, dado que em parte retorna em Os gigantes... como peça a ser encenada pela Companhia de Ilse. Incluiu-se ainda a narrativa para o terceiro ato, que teria sido ditada ao filho Stefano quando Pirandello já se encontrava no leito de morte. Considerando que, entre a denominação "mito" e o caráter inconcluso da obra, muitas leituras da peça perderam a possibilidade de compreender a modernidade teatral de Pirandello ao discutir o teatro em chave poética, sem tese e em narrativa transgressora de modelos tradicionais, nisto apostou a tradução: na poesia presente no próprio ato de inacabamento, na "falha". Com esse entendimento, o trabalho tradutório procurou "respeitar" a obra-fonte ali onde ela pretendeu ser poesia e até onde pôde poética e tragicamente chegar. E talvez também por isso, a tradução tenha ganho um plus de invisibilidade quando se empenhou em fazer explodir, pela língua brasileira, a estreita porta de ingresso determinada pela tradição de leitura Pirandello dramaturgo no Brasil, de que se tratou no primeiro segmento do texto. Enfim, alimentou-se a tradutora historiadora de uma ambiguidade, que, momentaneamente, acredita ter solucionado quando, frente ao complexo tema de entrada de 
Pirandello no Brasil e suas leituras, e frente ao texto que pôde escolher e acolher, a ele cedeu, inteiramente tomada por sua poesia.

Se é verdade que essa segunda versão cênica pelo Galpão da tradução de Os gigantes da montanha reitera os dados que levantamos a respeito de possíveis sentidos adquiridos pela contribuição da peça traduzida para a introdução de "outro" Pirandello, dramaturgo-poeta, no Brasil,19 é verdade também que para a discussão traz algo novo: além de se tratar de tradução levada a uma cena de vida mais longa, que permanece no repertório do grupo há seis anos e transita por diversas cidades do país, em festivais, ou não, essa versão brasileira de Os gigantes foi escolhida por um grupo que se dedica, continuadamente e por 30 anos, ao chamado "teatro popular e de rua". Note-se que a escolha da tradução, na verdade, deveu-se ao diretor Gabriel Villela, "de assinatura reconhecidamente barroca" em seu longo trajeto como encenador.

\section{Do erudito ao popular: a mesma tradução em cena}

Num dos depoimentos colhidos no making off em DVD do grupo (acervo Galpão), o diretor fala a respeito do estranhamento inicial que a peça causou junto aos atores; que os atores teriam "tremido na base", dada a dificuldade de levar o erudito Pirandello às classes populares. Ao nosso ver, diga-se, o estranhamento inicial dos atores frente à escolha do texto transformou-se em matéria da cena que levou em conta a "linguagem barroca" do diretor, as tradicionais experiências do grupo com circo-teatro e com mascaramento facial.

Fato é que aqui, com a mesma tradução, a ênfase da encenação do texto pirandelliano, recaiu no melodramático, unificando ainda mais a linguagem do diretor à trajetória de um grupo de atores de teatro de rua, e, assim, fazendo ver as variadas dimensões contidas na poesia pirandelliana que a tradução procurou "preservar" em sua escrita.

E destaque-se para os objetivos do presente texto que, se a leitura da tradução de Pirandello feita para essa montagem, por um lado, colaborou fortemente para o necessário desvendamento de um Pirandello poeta mais que 'cerebral', o fez, porém, carreando o protagonismo do mago Cotrone para a primeira atriz da companhia teatral, condessa decadente, Ilse Paulsen, de modo a levar o espetáculo a pendular entre uma carga lírico-poética "elevada" de Cotrone e uma lírico-"popular" melodramática de uma Ilse 'mineira", não poucas vezes desejada, e belamente realizada, de forma "caricata".

Quanto a questões tradutórias mais tradicionais, é necessário observar ainda que diante da ênfase na linguagem melodramática adotada, em acordo natural com as características do grupo e com a nova abordagem protagonista feminina pela qual se optou, a tradução sofreu alguns cortes, sem sofrer alterações de sentido, não indo

19 Para reforçar minha hipótese a respeito da relevância que as traduções e as montagens de Os gigantes da montanha adquirem para a entrada de um Pirandello dramaturgo de talho mais poético entre nós, vejam-se os dados disponibilizados pelo Galpão, computados desde a estreia pelo grupo, em maio de 2013 , até junho de 2919: "130 apresentações, 60 cidades. O público é aproximadamente 177.750 pessoas porque, como também apresentamos na rua, nossa soma se baseia em cálculos aproximados" (Peixoto, correspondência eletrônica, jun. 2019). É indiscutível, nesse sentido, o papel fundamental que a Petrobras, que há anos assina contratos de patrocínio com o Grupo Galpão, desempenhou com relação ao problema de que se está tratando. 
além de uma ou outra, de ordem vocabular. Por sua vez, em prol da compreensão do texto original e de sua tradução como "obras abertas", é necessário notar que dimensões lírico-poéticas do "mito" ou da "obra falha" continuam se infiltrando na cena, em diferentes momentos, seja pela densa carga poética presente na memória das tradicionais canções italianas cantadas, seja pela magia persistente, em diferentes naipes das diversas falas.

Não se está analisando o espetáculo, por certo, mas tratando das cargas poéticas possíveis emergentes no texto-fonte e acolhidas pela tradução levada à cena, cargas sobrepostas ao tema "de fundo" - em discussão experimentada, em metalinguagem que mal se percebe, posto que emborcada em tanta poesia -, aquele em torno do teatro e sua comunicabilidade. Trata-se de potências poéticas pouco observadas naquele Pirandello dramaturgo mais bem acolhido no Brasil, como se viu. ${ }^{20}$

Aqui também, afinal, haveria outro caso exemplar de tradução invisivel - no sentido problematizado por este texto -, fato que se pode atribuir, além dos motivos já discutidos, a alguns outros peculiares, a começar pelo próprio estranhamento do texto, que possivelmente teria solicitado a copresença de vários outros elementos, muito felizes em seu resultado, pois que, com exceção dos documentos que contemplam a ficha técnica ou de criação, qualquer outro acessado - desde a fortuna crítica contida no "Clipping Os gigantes da montanha completo - 3.12.2014" (acervo Galpão), gentilmente enviado pelo grupo, ao Diário de montagem do espetáculo, escrito por Eduardo Moreira, aos depoimentos contemplados no making off da montagem que integra o DVD - não faz referência à existência de uma tradução em cena.

Em duas entrevistas que realizei em março de 2015 - uma com Eduardo Moreira, ator que interpreta o mago Cotrone e um dos fundadores do Grupo Galpão, outra com Ernani Maletta, professor de música da Universidade Federal de Minas Gerais (UFMG), responsável pelos arranjos e pela preparação musical dos atores - foi possível avaliar que a questão da tradução não foi posta em questão ou como questão em momento algum do processo de montagem. À pergunta que fiz nessa direção, ouvi que a tradução não colocou qualquer problema, me dizendo Maletta que ela fluía, e que eu conseguira dizer em português o que dissera Pirandello.

A essa total transparência que o ato tradutório adquiriu para a montagem, junte-se a informação passada por ambos os entrevistados quanto ao fato de Francesca Della Monica, artista e professora italiana dedicada à vocalidade e musicalidade do ator, e responsável pelo trabalho vocal da montagem, ter dito, também como elogio, que ao ouvir o texto de minha tradução para o português, parecia estar ouvindo em italiano. (Rabetti, Amin, 2015a; 2015b).

20 Vale resgatar aqui, passagem de um dos maiores estudiosos do autor no Brasil, quando aprecia a montagem do texto de 1966, na tradução de Alberto D'Aversa, embora sem a comentar, mas legando, talvez, alguns indícios sobre ela a partir de sua colocação em cena: "Um espetáculo formalmente muito bonito. Uma encenação que se debruçou com o maior carinho sobre a obra de Pirandello. Mas, sem superar o hermetismo do texto, a montagem de Os gigantes da montanha, apresentada ontem para a crítica, no Teatro São Pedro, talvez não contribua para aproximar o público da arte, como parece ter sido a esperança final do dramaturgo italiano". (Magaldi, 1966, reproduzido em Magaldi, 2014, s.p.) 


\section{Considerações nada finais}

Ao final do presente texto, resultante, vale lembrar, de conferência proferida em 2015, e que acabou por incluir muitas atualizações para publicação em 2019, o conjunto de dados e reflexões apresentadas mantém uma dúvida fundamental: à derrocada da crença na possibilidade de uma completa migração de uma língua para outra, à bela abertura colocada por Ricoeur $(2005$, p. 20,21$)$ para a percepção de que o espaço da tradução se dá na perspectiva da hospitalidade que toda linguagem contempla, em que ponto do caminho poderá se situar o problema de uma sua total invisibilidade? E então que universo de questões tal fato poderá suscitar? Universo, aliás, a que mal afloramos.

Muitos outros dados foram coletados desde essa pergunta feita em 2015, muitos deles comunicados em eventos e publicados nos últimos anos, como já disse. Quero, porém, manter aqui uma consideração feita ainda em 2015, ditada pela direção de Gabriel Villela junto ao Galpão: talvez a criatividade da montagem aplicada ao "terceiro ato" de Os gigantes..., de Pirandello possa abrir espaço, se não para uma resposta "razoável", em termos da existência de uma tradução em cena, ao menos para dar asas a nossa imaginação.

Nos tablados de rua do Galpão, sob ruídos assustadores dos galopes dos gigantes pirandellianos, o autor Pirandello morre em cena, debruçado sobre sua mesa em ato de escrita aflita na impossibilidade de exprimir um final para sua peça. O narrador Cotrone se apresenta, informa a morte do autor e anuncia que, na ausência de suas palavras para o terceiro ato, os atores decidiram inventar eles próprios outras possibilidades. Inventam a cena num teatro de sombras (que mostra cenas da companhia se apresentando aos gigantes: o ator canastrão vaiado e a morte de Ilse despedaçada pelo público, tal como Pirandello, no leito de morte, teria narrado ao filho, acerca do terceiro ato que jamais pôde escrever). Diante da incompletude do texto, da presença de um terceiro ato, ditado ao filho de Pirandello ou por ele imaginado - fonte dramatúrgica inexistente, que a tradução não poderia traduzir, mas apenas narrar inventa-se na cena uma língua intraduzível.

Diante da ausência do texto dramático e de sua tradução, o Galpão preenche a cena com magnífica partitura de um grommelot de base sonora grega, e onomatopeica, criada pelos atores, para narrar a cena que Pirandello teria narrado ao filho e que a tradução reproduzira.

Ao fim, o que se tem em cena, na ausência da palavra do autor e de sua tradução, é a contínua busca de seus ecos, em conjugação com o trabalho atorial continuamente preparado no seio de um grupo de longa duração (com Os gigantes da montanha comemoram-se 30 anos do grupo e seus muitos trabalhos com o diretor Gabriel Villela, reitera-se); conjugação rara, que não pode deixar de nos inspirar em tradições teatrais de ainda mais longa duração, tal como a da commedia dell'arte italiana, que jamais deixou de instigar o autor italiano e sua dramaturgia, nem tampouco a cena contemporânea. ${ }^{21}$

21 E se me é permitido dizer, instiga também a tradutora há muitos anos. O que, porém, importa destacar aqui é que também por este pequeno grande detalhe, o da relação do dramaturgo e encenador Pirandello com a marcante tradição teatral italiana, fosse outro o objetivo do presente texto, seria possível lembrar Piran- 
Fato é que a radical impossibilidade da tradução do grommelot - no lugar de um texto que o autor jamais escreveu, mas para o qual apontou, dada a impermeabilidade da matéria de que é feita a língua onomatopaica, mesmo que encene a morte do autor e o limite do tradutor - acaba por revelar o desejo de continuar ouvindo sua voz, pois o vagalampos do grommelot - palavra proferida como encerramento da cena trágica jamais escrita e intraduzível, mas pela história disponibilizada em invenção narrativa - pode indicar que, na poesia de Pirandello inconclusa e por isso interminável, nos limites de traduções brasileiras possíveis, o que irrompeu poética e inesperadamente em vagalampos - na conjugação extraordinária de vagalume, pirilampo, lampo, lampi - foi a conexão de duas línguas "hospedeiras", em longa história de convivências culturais, nem sempre sem tensões e atritos, mas, até o momento, afetiva e historicamente hospitaleiras diante do universo de adversidades e diversidades em que também o mundo da tradução tem que submergir para subsistir.

(Sobe o pano que vai servir como divisória. Três sinais.)

(...)

(A cortina se abre para o início da Fábula. Silêncio)

SPIZZI

- Sanefa córtilex pólis drômo. Metáforas!

SPIZZI

- Minotauros monstra piós... Eno bacos ébria pseudo sentáculos

BATALHA

- Canastrópoli Cromo pros quênio... Cromo satírico actor piós burrâmia CROMO

- Actor piós burrâmia concreta? Ésquilo: artembares, artembares, antitese olimpus.

(Som de palmas e risadas)

DIAMANTE - Hecatônquiros calidora... Cânfora!

CROMO - Ágora tê poiésis!!!

(Vaias e gritos)

Bella Ciao

"Ancreta monte papilografo

Oh vive rái, vive rái, vive rái

Ancreta monte papilografo

Kakoianis antropós

Antropoianis minexidêmia

Oh vive rái, vive rái, vive rái

Antropoianis minexidêmia

Triunfocus piteron

(Ilse entra em cena. Pausa)

ILSE - Eskafe felos Kassandra logus báfula noi

Mapuro kádia Hécuba de safos

Piós mapuro minâncora esc

Kanekalon mater

Kaloscopáico própolis

Katastimat, piton katastimata!

(Nova onda de vaias.)

\footnotetext{
dello, suas "falhas" e ambiguidades pelo lugar imperativo que ocupa nessa especial forma de transição dramatúrgica e cênica, e não apenas italiana, para o teatro moderno. Para ficar todavia na exata medida dos propósitos deste texto, acredito poder dizer que, tanto um determinado exercício de tradução teatral realizado como sua colocação em cena por um modo de atuar/encenar Galpão/Vilela colaboraram grandemente para que se abrissem, no seio de modos de ler Pirandello no Brasil, outras portas de entendimento e experimentação de um Pirandello poeta, se não maior, grandemente admirável, a conversar com aquele tão conhecido entre nós, o pensador atormentado e assombrado por suas teses teatrais sobre o teatro. Pequenas e grandiosas frestas que apontam para um Pirandello situado às portas do teatro moderno, de modo bastante singular, ali onde, do mesmo modo, se o vê no limiar de poéticas teatrais italianas, sicilianas ou não.
} 


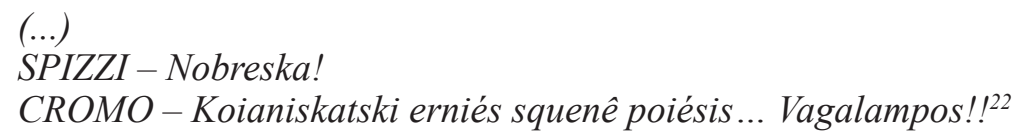

\section{Referências}

ARAÚJO, A. Com entrada franca, Galpão estreia 'Os gigantes da montanha' em BH. O Globo. Minas Gerais (G1). 21.05.2013. Disponível em http://g1.globo.com/minas-gerais/noticia/2013/05/com-entrada-franca-galpao-estreia-os-gigantes-da-montanha-em-bh.html. Acesso em: 26 jun. 2019.

ASTROS em Revista, 2012. Disponível em http://astrosemrevista.blogspot.com. br/2012/01/cleyde-yaconis-no-teatro.html. Acesso em: 17 maio 2019.

BINA, S. S. O jogo dos papéis: um estudo sobre a personagem dramatúrgica em Seis personagens à procura de um autor, de Luigi Pirandello. Dissertação (Mestrado em Letras). Universidade Federal de Minas Gerais, Belo Horizonte, 2007. Disponível em http://www.bibliotecadigital.ufmg.br/dspace/bitstream/handle/1843/ECAP-73QLDF/dissertaçao_final.pdf? sequence=1. Acesso em: 14 maio 2019.

BIBLIOTECA Jenny Klabin Segall, São Paulo. Disponível em http://www.mls.gov.br/ biblioteca/catalogo-online/, acesso em 14.05 .2019 e em http://www.bjksdigital.museusegall.org.br/index.html. Acesso em: 14 maio 2019.

CETRA, J. Os gigantes da montanha. Palco paulistano. Pontos de vista de um espectador.... São Paulo, 24 de setembro de 2013. Disponível em http://palcopaulistano. blogspot.com/2013/09/os-gigantes-da-montanha.html. Acesso em: 20 maio 2019.

DIAS, M. S. Pirandello em cinco atos. São Paulo: Carambaia, 2017.

DUGO, Sandra. Storia della translatio del corpus pirandelliano in Brasile. Revista de Italianística, n. 34 (2017). Disponível em http://www.revistas.usp.br/italianistica/article/view/139849. Acesso em: 2 jun. 2019.

FABRIS, A, \& FABRIS, M. Presença de Pirandello no Brasil. In: GUINSBURG, J. (org). Pirandello: do teatro no teatro. Reimpressão. São Paulo: Perspectiva, 2009, p. 385-405.

FABRIS, A, \& FABRIS, M. Presença de Pirandello no Brasil. In: GUINSBURG, J. (org). Pirandello: do teatro no teatro. São Paulo: Perspectiva, 1999, p. 385-405.

22 Agradeço publicamente ao Galpão pelo envio de vários documentos (textos e imagens) trabalhados no texto, com cessão de direitos para sua publicação no presente artigo. Em especial, o envio do texto da cena final em grommelot (acervo Galpão), que reproduzo parcialmente; documento cênico de extrema significação, como acredito ter demonstrado, para a discussão da "invisibilidade" ou da "impossibilidade" da tradução teatral. Por outro lado, quero informar que texto e tradução continuam explodindo em possibilidades para a presença da poesia pirandelliana entre nós, que neste mês de junho de 2019, volta a transbordar, na história em quadrinhos, de mesmo título e com minha tradução, Os gigantes da montanha. (Pirandello, 2019) 
FLAKSMAN, S. Seis personagens à procura de autor: uma comédia a ser criada. São Paulo: Peixoto Neto, 2004.

FUNARTE. Portal Fundação Nacional de Artes, Rio de Janeiro. Disponível em http:// portais.funarte.gov.br/brasilmemoriadasartes/. Acesso em: 14 maio 2019.

GUINSBURG, J.; BARNI, R. Seis personagens à procura de um autor. In: GUINSBURG (org.). Pirandello: do teatro no teatro. São Paulo: Perspectiva, 1999, p. 181-239.

HISTÓRICO - Escola de Teatro. Disponível em: http://www.Unirio.br/cla/escoladeteatro/historico. Acesso em: 25 jun. 2019)

KREMER, K. Análise descritiva das traduções brasileiras de Vestire gli ignudi, de Luigi Pirandello. Dissertação (Mestrado em Estudos da Tradução). Universidade Federal de Santa Catarina, Florianópolis, 2012. Disponível em: https://repositorio.ufsc.br/. Acesso em: 14 maio 2018.

KREMER, K. Tradução de um poema de Luigi Pirandello: um exercício comentado. In:Traduções. Revista do Programa de Pós-Graduação em Estudos da Tradução da UFSC. Universidade Federal de Santa Catarina, Florianópolis. Volume 3. Número 4, 2011. Acesso em: 24 jun. 2019.

Hemeroteca Digital da Biblioteca Nacional. https://bndigital.bn.gov.br/hemeroteca-digital/

LE GOFF, Jacques. Documento e monumento. Trad. Suzana Ferreira Borges. In: LE GOFF, Jacques. História e memória. Trad. Bernardo Leitão et al. Campinas: Editora da Unicamp, 1990. Disponível em: https://www.ufrb.edu.br/ppgcom/images/Hist\%C3\%B3ria-e-Mem\%C3\%B3ria.pdf), p. 462- 473. Acesso em: 12 jun. 2019.

MACIEL, P. M. C. A cultura dramática do século XIX no Brasil vista do acervo da Fundação Biblioteca Nacional. Sala Preta, São Paulo, v. 2, 2017. Disponível em: http://www. revistas.usp.br/salapreta/article/view/139717. Acesso em: 15 jun. 2019.

MAGALDI, S. Os gigantes da montanha - 04/07 - Dir.Federico Pietrabruna. In: Amor ao teatro. São Paulo: Sesc, 2014. Acessível em https://books.google.com. br/books? id=thG3CwAAQBAJ\&pg =PT133\&lpg=PT133\&dq=Os+gigantes+da+montanha+\%E2\%80\%93+Federico+Pietrabruna\&source $=$ bl\&ots $=$ GesBdHmKJX\&sig=ACfU3U3-4-Z1FI2N9_81A2kjYTOjKOCxBQ\&hl=pt-BR\&sa=X\&ved=2ahUKEwjOm5727oTjAhViHbkGHShAAWEQ6AEwCHoECAkQAQ\#v=onepage\&q=Os\%20 gigantes $\% 20$ da\%20montanha\%20\%E2\%80\%93\%20Federico\%20Pietrabruna\&f=false. Acesso em: 25 jun. 2019.

MAGALDI, S. Prefácio. In: Vestir os nus. Luigi Pirandello. Trad. Ruggero Jacobbi. São Paulo: Brasiliense, 1966. 
MARLOWE. C. A trágica história do Dr. Fausto. Trad. Maria de Lourdes Rabetti, 1989 [tradução integral da peça, autorizada, a partir da versão italiana, em prosa, de Maria Antonieta Andreoni D' Ovidio (Utet, 1981)].(inédito).

MELO, S. N. Assim é (se lhe parece). São Paulo: Tordesilhas, 2011.

MERCADO NETO, Antônio. Crítica teatral de Alberto D'Aversa no Diário de São Paulo. Dissertação (Mestrado em Teatro), Universidade de São Paulo, 1979.

MICHALSKI, Y. D'Aversa, um mestre que perdemos - De Roma para o Brasil. Jornal do Brasil, 4 de julho de 1969, p.2 (Caderno B; coluna Teatro) Acessível em http://memoria.bn.br/DocReader/docreader.aspx?bib=030015_08\&pasta=ano\%20196\&pesq. Acesso em: 23 maio 2019.

MOREIRA, E. Grupo Galpão: Diário de montagem, v.10 - Os gigantes da montanha. Belo Horizonte: CPMT, 2014.

PASQUALINI, J. T. F. Encontro e confronto do (in)visível na tradução do romance II fu Mattia Pascal, de Pirandello. Dissertação (Mestrado em Teoria Literária). Universidade Federal de Santa Catarina, Florianópolis, 2005. Disponível em: https://repositorio. ufsc.br/handle/123456789/101802. Acesso em: 14 maio 2019.

PIRANDELLO, L. I giganti della montagna - mito. In: Maschere Nude, v. 2. Milão: Mondadori, 1981, p. 1305-1376.

PIRANDELLO, L. Os gigantes da montanha. Trad. Maria de Lourdes Rabetti (Beti Rabetti). História em Quadrinhos (decupagem de Inês Peixoto). Minas Gerais; São Paulo: Autêntica, 2019.

PIRANDELLO, L. Os gigantes da montanha. 2 ed. Trad. Maria de Lourdes Rabetti (Beti Rabetti). Rio de Janeiro: 7Letras, 2013.

PIRANDELLO, L. Os gigantes da montanha. Trad. Maria de Lourdes Rabetti (Beti Rabetti). Rio de Janeiro: 7Letras, 2005.

RABETTI, M.L. O trânsito de Pirandello por Rio e São Paulo no início dos anos 20: cerebralismo, ímpetos e impurezas no processo de modernização teatral no Brasil. São Paulo, USP-TUSP, Companhia do Latão, 29.11.2018. (Palestra, inédita).

RABETTI, M.L. Pois é...isso!: trânsitos e transações da tradução teatral. In: Congresso da Associação Brasileira de Pesquisa e Pós-Graduação em Artes Cênicas, 9., 2017b. Uberlândia. Anais.... Uberlândia, 2017. Disponível em https://goo.gl/RQ8UA3. Acesso em: 20 maio 2019 
RABETTI, M. L. Em busca da tradução teatral: o trabalho do historiador em meio a miudezas da cena e precariedades documentais. Sala Preta, São Paulo, v. 17, n.2, p. 4871, 2017a. Disponível em https://www.revistas.usp.br/salapreta/article/view/139972. Acesso em: 20 maio 2019.

RABETTI, M.L. Tradução e cena: a busca pela poesia pirandelliana. In. Luigi Pirandello - Os gigantes da montanha. Trad. Maria de Lourdes Rabetti. Rio de Janeiro: 7Letras, 2013, p. 7-9. (Prefácio à segunda edição)

RABETTI, M. L. O laboratório do Dramaturg e os estudos de genética teatral: experimentos. In: Revista Brasileira de Estudos da Presença. V.1, n. 2, 2011, p. 443-458. http://www.seer.ufrgs.br/index.php/presenca/issue/view/1452/showToc. Acesso em: 15 jun. 2019.

RABETTI, M.L. Sobre Os gigantes da montanha e sua tradução. In. Luigi Pirandello Os gigantes da montanha. Trad. Maria de Lourdes Rabetti. Rio de Janeiro: 7Letras, 2005, p.7-11. (Prefácio)

RABETTI, M.L. Sobre a tradução. In: Os gigantes da montanha - Luigi Pirandello. "In honore di Marta Abba". Rio de Janeiro: Companhia de Encenação Teatral, 1991 (Programa da peça).

RABETTI, M.L.; AMIN, P. V. Entrevista com Eduardo Moreira. Belo Horizonte, 9.3.2015a. (inédita)

RABETTI, M.L.; AMIN, P. V. Entrevista com Ernani Malleta. Belo Horizonte, 9.3.2015b. (inédita)

RIBEIRO, M.M. Luigi Pirandello: um teatro para Marta Abba. São Paulo: Perspectiva, 2010.

RICOEUR, Paul. Sobre a tradução. Lisboa: Cotovia, 2005.

SCHENKER, Daniel. Pirandello com a marca do Galpão. In WordPress. 2013. Disponível em: https://danielschenker.wordpress.com/2013/10/13/pirandello-com-a-marca-do-galpao/. Acesso em: 20 maio 2019.

SCHENKER, Daniel. Teatro dos 4: a cerimônia do adeus do teatro moderno. Rio de Janeiro: 7Letras, 2018.

SIAN (Sistema de Informações do Arquivo Nacional). Rio de Janeiro. Disponível em: http://sian.an.gov.br/sianex/consulta/login.asp. Acesso em: 15 maio 2019.

SZONDI, P. Teoria do drama moderno (1880-1950). São Paulo: Cosac \& Naify, 2001. 